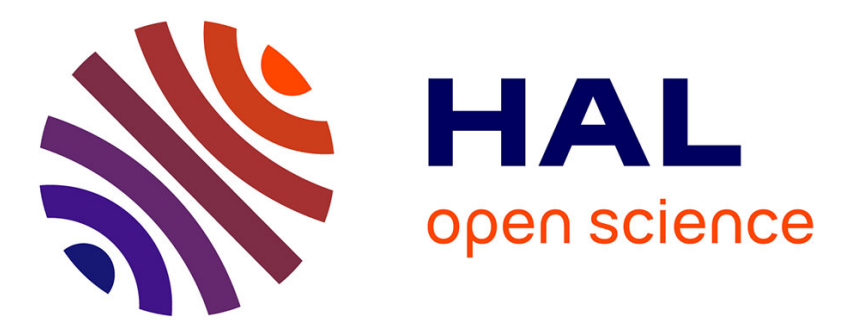

\title{
Potential source regions of biogenic aerosol number concentration apportioning at King George Island, Antarctic Peninsula
}

Alexandre Alencar, Heitor Evangelista, Elaine dos Santos, Sergio Correa, Myriam Khodri, Virginia M.T. Garcia, Carlos A.E. Garcia, Enio Pereira, Alberto Piola, Israel Felzenszwalb

\section{To cite this version:}

Alexandre Alencar, Heitor Evangelista, Elaine dos Santos, Sergio Correa, Myriam Khodri, et al.. Potential source regions of biogenic aerosol number concentration apportioning at King George Island, Antarctic Peninsula. Antarctic Science, 2010, 22 (5), pp.580-588. 10.1017/S0954102010000398 . hal03199872

\section{HAL Id: hal-03199872 \\ https://hal.science/hal-03199872}

Submitted on 18 Apr 2021

HAL is a multi-disciplinary open access archive for the deposit and dissemination of scientific research documents, whether they are published or not. The documents may come from teaching and research institutions in France or abroad, or from public or private research centers.
L'archive ouverte pluridisciplinaire HAL, est destinée au dépôt et à la diffusion de documents scientifiques de niveau recherche, publiés ou non, émanant des établissements d'enseignement et de recherche français ou étrangers, des laboratoires publics ou privés. 


\title{
Potential source regions of biogenic aerosol number concentration apportioning at King George Island, Antarctic Peninsula
}

\author{
ALEXANDRE S. ALENCAR ${ }^{1}$, HEITOR EVANGELISTA ${ }^{1}$, ELAINE A. DOS SANTOS ${ }^{1}$, SERGIO M. CORREA $^{2}$, \\ MYRIAM KHODRI ${ }^{3}$, VIRGINIA M.T. GARCIA ${ }^{4}$, CARLOS A.E. GARCIA ${ }^{5}$, ENIO B. PEREIRA ${ }^{6}$, \\ ALBERTO R. PIOLA ${ }^{7}$ and ISRAEL FELZENSZWALB ${ }^{1}$ \\ ${ }^{1}$ Laboratório de Radioecologia e Mudanças Globais, Universidade do Estado do Rio de Janeiro, Rua São Francisco Xavier 524, \\ PHLC - Subsolo, Maracanã, 20550-013 RJ, Brazil \\ ${ }^{2}$ Universidade do Estado do Rio de Janeiro, Departamento de Química Ambiental, Faculdade de Tecnologia, \\ Rodovia Presidente Dutra, km 298, Resende, 27537-000 RJ, Brazil \\ ${ }^{3}$ UR Paleotropique, Institut de Recherche pour le Développement, 32 Avenue Henri Varagnat, 93143 Bondy Cedex, \\ France/Laboratoire des Science du Climat et Environnement (LSCE), Gif-sur-Yvette, France \\ ${ }^{4}$ Fundação Universidade Federal do Rio Grande, Departamento de Oceanografia, Lab. Ecology of Phytoplankton and \\ Marine Microorganisms, Av. Itália, km 8, Rio Grande, 96201-900 RS, Brazil \\ ${ }^{5}$ Fundação Universidade Federal do Rio Grande, Departamento de Física, Laboratório de Oceanografia Física, Av. Itália, \\ km 8, Rio Grande, 96201-900 RS, Brazil \\ ${ }^{6}$ Instituto Nacional de Pesquisas Espaciais, Departamento de Geofisica Espacial, Av. dos Astronautas 1758, Cx. Postal 515, \\ 12201-970 São José dos Campos, SP, Brazil \\ ${ }^{7}$ Departamento Oceanografía, Servicio Hidrografía Naval and Departamento de Ciencias de la Atmósfera y los Océanos, FCEN, \\ Universidad de Buenos Aires, Avenida Montes de Oca 2124, Buenos Aires, Argentina \\ alencar@uerj.br
}

\begin{abstract}
Nowadays it is well accepted that background aerosols in the boundary layer over remote oceans are of marine origin and not aged continental. Particularly in the Atlantic sector of the Southern Ocean at least four main important regions exhibit significant ocean primary productivity. They are the Bellingshausen-Amundsen Sea, the Weddell Sea, the southern Argentinean shelf and the southern Chilean coast. In this work, we have combined ground-based continuous atmospheric sampling of aerosol number concentration (ANC), over-sea dimethyl sulphide (DMS) measurements, chlorophyll $a$ (chl $a$ ) concentration provided by Sea-viewing Wide Field-of-view Sensor (SeaWiFS) satellite images, in situ meteorological data and monthly regional NCEPNCAR re-analysis wind fields in order to investigate the relative contribution of each of the above regions to the apportionment of the ANC at King George Island (KGI), South Shetland Islands. Our results suggest that, at least during the period from September 1998-December 1999, the southern Argentinean shelf acted as the main contributor to the ANC measured in KGI.
\end{abstract}

Received 29 June 2009, accepted 12 May 2010

Key words: Antarctica, atmospheric transport, chlorophyll $a$, dimethyl sulphide

\section{Introduction}

A bio-geochemical cycle was proposed by Charlson et al. (1987) that includes the production of dimethylsulphoniopropionate (DMSP), by phytoplankton enzymatic activity, a precursor compound to the volatile dimethyl sulphide (DMS, $\mathrm{CH}_{3} \mathrm{SCH}_{3}$ ). The release of DMS from the surface ocean, followed by both oxidation to non-sea salt sulphate $\left(\right.$ nss- $\left.\mathrm{SO}_{4}{ }^{2-}\right)$ and methanesulphonic acid (MSA, $\mathrm{CH}_{3} \mathrm{SO}_{3} \mathrm{H}$ ) formation, may act as cloud condensation nuclei (CCN) sources for marine cloud formation. Furthermore, this mechanism (named the 'CLAW hypothesis') became a potential link between the marine biogenic aerosols and climate changes. According to Andreae \& Crutzen (1997), changes in CCN concentration affect the concentration number of cloud droplet, which in turn influences cloud albedo and ultimately the climate.
Additionally, numerous studies have already revealed that sulphate aerosols participate in the earth-atmosphere radiation budget by partially scattering and reflecting the incoming solar radiation (Langmann et al. 1998, Kirkevag et al. 1999).

Fine continental dust blown from the Patagonian semidesert (McConnell et al. 2007) together with non-sea salt sulphate particles constitute important sources to the total suspended aerosol concentration in the Southern Ocean. On King George Island (KGI), South Shetland Islands, located to the north-east of the Antarctic Peninsula tip $\left(62^{\circ} \mathrm{S}\right.$, $58^{\circ} \mathrm{W}$ ), terrigenous enriched aerosols of $\mathrm{Al}, \mathrm{Si}, \mathrm{K}, \mathrm{Fe}, \mathrm{Ti}$, $\mathrm{Mn}$ and Sr were monitored by Correia et al. (1998) between 1985 and 1993 at the Brazilian Antarctic station Comandante Ferraz $\left(62^{\circ} 05^{\prime} \mathrm{S}, 58^{\circ} 23.5^{\prime} \mathrm{W}\right)$. Analysis of these data revealed no significant seasonal behaviour, but a structure formed by peaks of short duration and periods of low concentrations. 
In contrast, the total atmospheric $\mathrm{S}$ in the fine mode aerosol (aerodynamic diameter $<2.5 \mu \mathrm{m}$ ) presented marked intraannual variability with a minimum $\left(c .50 \mathrm{ng} \mathrm{m}^{-3}\right)$ in the midwinter (May-July) and a maximum $\left(200 \mathrm{ng} \mathrm{m}^{-3}\right)$ in summer (November-February). A similar behaviour was observed from $\mathrm{Br}$ measurements. Additionally, aerosol number concentrations (ANC), monitored at the same site, also exhibited a similar marked seasonal pattern as total S (Dalia et al. 2004). The above patterns reinforce the findings of Fitzgerald (1991) who stated that the background aerosols in the boundary layer over remote oceans is of marine origin, and not aged continental. In addition, Vallina et al. (2006) have shown that in the Southern Ocean region satellite-derived AOD (aerosol optical depth), an indicator of $\mathrm{CCN}$ in the lower atmosphere, is positively correlated with satellite-derived chlorophyll $a$ (chl $a$ ) concentration on a seasonal basis.

There are several regions in the Southern Ocean where remote sensing techniques and/or field measurements have estimated significant chl $a$ concentrations ( $\left.>2 \mathrm{mg} \mathrm{m}^{-3}\right)$ : 1) the north-western Weddell Sea and Bellingshausen-Amundsen Sea (Moore \& Abbott 2000), 2) the Scotia Sea (Holm-Hansen et al. 2004), 3) the Ross Sea (Pabi \& Arrigo 2006), 4) the southern Chilean coast (Toro et al. 1999), and 5) the Argentinean continental shelf (Gayoso 2001, Saraceno et al. 2005, Romero et al. 2006, Rivas 2006, Rivas et al. 2006, Signorini et al. 2006). In the last two decades, the marginal sea ice zone has also been recognized as a major area of intense primary production in the Southern Ocean (Lizotte 2001). Large phytoplankton blooms occur in areas where the sea ice retreats periodically in the Weddell Sea (e.g. c. $60^{\circ} \mathrm{S}, 30^{\circ} \mathrm{W}$ ). Nevertheless, a few phytoplankton species are recognized to have significant bio-geochemical impacts at the global climate scale. Particularly in the Southern Ocean, one can highlight the presence of diatoms and the haptophyte Phaeocystis sp. (mainly Phaeocystis antarctica Karsten) as major contributors to the regional primary productivity (Arrigo et al. 2000, Ditullio et al. 2000, Garibotti et al. 2003).

In remote regions, ANC components derive basically of particles from DMS oxidation, marine primary organic matter, marine secondary organic aerosols, sub-micron dust particles and sub-micron sea salt. A previous study by Crocker et al. (1995), of the Southern Ocean, has found an $r^{2}$ value between chl $a$ and DMS concentrations of 0.356 $(n=30)$ for surface waters. DMS oxidation products such as MSA and $\mathrm{SO}_{4}^{-2}$ particles are highly hygroscopic and exist predominantly in the size fraction ranging between 0.1 and $1 \mu \mathrm{m}$ in diameter, which is the optimal size range for $\mathrm{CCN}$ formation. A spectral analysis applied to the elemental composition time series obtained at the study site (Correia et al. 1998) has not indicated any cyclic pattern. In contrast, surges of $\mathrm{Al}, \mathrm{Fe}, \mathrm{Ca}$ and $\mathrm{Ti}$ occurred randomly during all the seasons suggesting no evidence of a seasonal dust transport regime towards the Antarctic Peninsula,

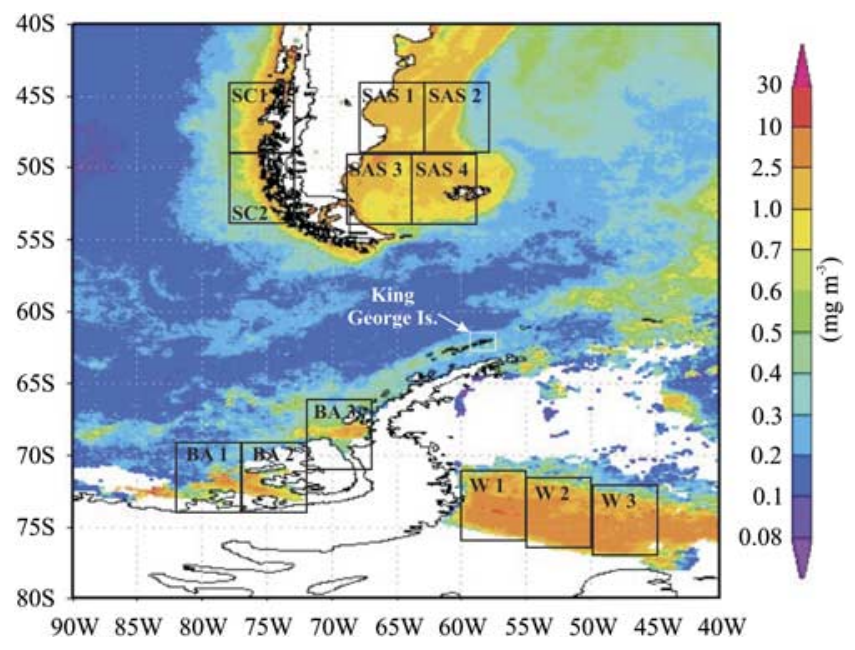

Fig. 1. Mean chl $a$ concentration composite image obtained from SeaWiFS images, corresponding to the period September 1997-December 1998. Square boxes defined as BA1, 2, and 3 refer to Bellingshausen-Amundsen Sea sector; W1, 2, and 3 to Weddell Sea sector; SAS1, 2, 3, and 4 to southern Argentine shelf sector and SC1 and 2 to southern Chilean coast sector. KGI location is indicated by an arrow.

characterized by increases in the summer season. The same is valid for the wind intensity. On the other hand, DMS peaks during the summer season in several sub-Antarctic areas as compiled by Turner et al. (1995). Also, Vallina et al. (2006) have demonstrated that for the Southern Ocean $\left(40-60^{\circ} \mathrm{S}\right)$, the seasonal $\mathrm{CCN}$ concentrations are characterized by a clear pattern of higher values during the summer and lowering towards the winter. Therefore, dust and sea salt variability at KGI cannot support the well marked interannual characteristic of ANC data.

Besides the geochemical parameters used as proxies of ocean primary productivity, related to the atmospheric measurements or ice core analysis, the variability of ANC may reflect the impact of biogenic and marine sources at the regional context of this work. Herein, we have investigated the correlation between ANC and chl $a$ at four important productivity sites revealed by remote sensing (the Bellingshausen-Amundsen Sea, Weddell Sea, southern Argentinean continental shelf and southern Chilean waters) from September 1997-December 1998. During this time, the northern sector of the Antarctic Peninsula, where KGI is located, was subjected to the meteorological influences from all the above regions, due to the westerly winds, polar air masses and warmer air and moisture advection from South America (Turner 2004). Besides that, inertial jet streams originating in the Weddell Sea are potentially responsible for considerable lowering of the air temperature in that region (Setzer \& Harter 2004). Here a compilation of ocean-colour satellite images of Sea-viewing Wide Field-of-view Sensor (SeaWiFS), local wind databases obtained from an Automatic Weather Station (AWS), 
regional wind current charts compiled from NCEP/NCAR re-analysis, in combination with the ANC time-series obtained at KGI was conducted.

\section{Study area}

The study area covers the region between $40-80^{\circ} \mathrm{S}$ and $40-90^{\circ} \mathrm{W}$ in the Southern Ocean (Fig. 1). Atmospheric sampling of ANC was conducted at KGI where more than $92 \%$ of its area is ice covered and elevations reach approximately $700 \mathrm{~m}$ a.s.l. (Braun et al. 2004). According to Ferron et al. (2004), considering the period from 1947-95, the mean annual temperature on this island was $-2.8^{\circ} \mathrm{C}$ with a minimum of $-5.2^{\circ} \mathrm{C}(1959)$ and a maximum of $-0.8^{\circ} \mathrm{C}(1989)$.

The Bellingshausen-Amundsen Sea sector comprises the longitude band from $130-60^{\circ} \mathrm{W}$. It corresponds to an area of $8 \times 10^{6} \mathrm{~km}^{2}$, which presents the second largest extent of frozen sea in West Antarctica during the summer season. The Weddell Sea sector (from $60-20^{\circ} \mathrm{W}$ ) covers $12 \times 10^{6} \mathrm{~km}^{2}$ and is characterized by relatively cold ocean waters and large areas of perennial sea ice influenced by both the presence of a semi-permanent high pressure system and by polynyas, which result from katabatic winds derived from the Antarctic plateau (Gloersen et al. 1992). The southern Argentinean shelf sector is located between $40-55^{\circ} \mathrm{S}$ in the Atlantic Ocean, while the southern Chilean coast sector comprises part of the southern Chilean coast $\left(40-55^{\circ} \mathrm{S}\right.$ at the Andean Pacific side).

Diatoms and haptophytes are abundant in the entire Southern Ocean but the relevant species involved in the DMS cycle have a geographically variable distribution, according to several authors. For instance, Phaeocystis antarctica (haptophyte) and Nitzschia subcurvata Hasle (diatom) are abundant in the Weddell Sea (Lizotte 2001), whereas only P. antarctica predominates in the Bellingshausen-Amundsen Sea. In the southern Chilean coast sector, the most abundant diatom is Skeletonema costatum (Grev.) Cleve followed by Nitzschia closterium (Ehrenberg) W. Sm., Melosira sp. and several species of the genus Coconeis and Clavicula (Toro et al. 1999). In the southern Argentinean shelf sector phytoplankton species vary both geographically and in time within the summer season (Gayoso 2001), with the occurrence of Skeletonem costatum several Chaetoceros species, Phaeocystis spp. and Coccolithophorid species like Emiliania huxleyii (Loh.) Hay \& Mohl., known as an important DMS producer. Still according to this author, in this region the phytoplankton distribution is dominated by seasonal occurrence of diatoms. In spring, the phytoplankton assemblage in the shelf-break was shown to be dominated by diatoms of the genus Thallasiosira and the haptophyte Phaeocystis sp., the latter particularly associated with high DMS production.

\section{Databases and methods}

Atmospheric sampling of ANC was conducted from September 1997-December 1998 on KGI at the atmospheric science module, located $1.8 \mathrm{~km}$ from the Comandante Ferraz station. The measurements of ANC were performed by a condensation nuclei counter, Model 3760 of TSI ${ }^{\circledR}$ Incorporated. Concentration values (in particle per cubic centimetre, $\mathrm{N} \mathrm{cm}^{-3}$ ) were available at 10 minute intervals. The instrument allows detection of atmospheric particulates with diameters larger than $0.014 \mu \mathrm{m}$. Details on the operation and general characteristics of this equipment can be found in Maring \& Schwartze (1994) and Dalia et al. (2004). Instrument failure interrupted the atmospheric sampling during October 1997.

Atmospheric samplings for ANC at the Argentine continental shelf were performed using a wind sector control system to prevent contamination from the ship's exhaust. An aerosol inlet (a cylindrical tube of $20 \mathrm{~cm}$ length and $15 \mathrm{~cm}$ width) was used to protect the system from sea spray. It was positioned at the top of the ship (10 m a.s.l.), $50 \mathrm{~m}$ away from the ship stack's emission, while the pumping unit and the condensation nuclei counter were installed inside the ship and consisted of one pump unit (one-head GAST model) and a wind sector sampling control, which is an electronic device connected to an anemometer (installed beside the inlet compartment), a data logger, a two-way electrical valve and pumps. It was internally programmed to interrupt the aerosol sampling any time the wind blew within an angular sector (named 'dirty sector') of $60^{\circ}$ centred at a line between the inlet and the ship's exhaust. This way, any time the wind blew into the inside of the 'dirty sector' the airflow connection between the filter holder and the pump was interrupted through a two-way electrical valve.

In order to obtain a latitudinal profile of atmospheric DMS (the most probable source of ANC over sea) in the south-western Atlantic and Southern Ocean, we performed measurements on board the Ary Rongel oceanographic vessel during the 2005 summer campaign. Air samples were concentrated in glass cartridges, containing 200/ $400 \mathrm{mg}$ sorbent of coconut shell charcoal (SKC 226-09), installed in the inlet of a continuous air pumping system of controlled flux of $11 \mathrm{~min}^{-1}$. Each flask was sealed after approximately $1^{\circ}$ latitude integration on board. Extraction of DMS occurred under laboratory conditions at Rio de Janeiro State University, Brazil with the use of $1 \mathrm{ml}$ of cold dichloromethane followed by $10 \mathrm{~min}$ ultrasound. DMS detection was performed by gas chromatography (Agilent 6890) with selective mass detector Agilent MSD 5973, making use of $1 \mu \mathrm{l}$ of sample, in splitless mode, using helium as carrier gas at $1.0 \mathrm{ml} \mathrm{min}^{-1}$. Temperature profile of the chromatographic column was $40^{\circ} \mathrm{C}$ for $6 \mathrm{~min}$, followed by a linear increase of $10^{\circ} \mathrm{C} \mathrm{min}^{-1}$ until $200^{\circ} \mathrm{C}$. Detection mode was the single ion monitoring SIM: 32,71 and $86 \mathrm{~m} /$ $z$, with ionization source energy of $70 \mathrm{eV}$. Uncalibrated values attributed to DMS were based on the peak area obtained from the respective chromatogram.

Satellite-derived chl $a$ concentration was obtained from SeaWiFS data, available at the NASA's Goddard Space Flight 
Centre (GSFC) and Distributed Active Archive Centres (DAAC) at the 'Giovanni Ocean Color Time Series Online Visualization and Analysis' website (http://reason.gsfc.nasa. gov/OPS/Giovanni/ocean.aqua.shtml, accessed August 2006). The chl a SeaWiFS images $\left(9 \times 9 \mathrm{~km}^{2}\right.$ resolution) were generated based on the global OC4v4 algorithm. SeaWiFS data acquisition in oceanic areas is constrained by cloud cover, sensor sensitivity and by seasonal sea ice cover. Chl $a$ concentrations over the Bellingshausen-Amundsen Sea is generally available for the January-April and AugustDecember periods. Databases for the period May-July are constrained by the absence of sunlight and sea ice formation. For the Weddell Sea, there was lack of information over the period April-October.

For the south-western Atlantic region, the NASA OC4v4 algorithm presented a reasonable performance $\left(r^{2}=0.87\right)$ compared to the revised algorithm for south-western Atlantic data (Garcia et al. 2005). At that site, despite the relatively low number of pairs of radiometric measurements, SeaWiFS estimations compare well with in situ chl $a$ concentrations $\left(0.77<r^{2}<0.98, n=21\right)$. Regarding the chl $a$ concentration, an overall agreement was observed $\left(r^{2}=0.77, n=28\right)$, with a mean absolute percentage difference of $66 \%$, which is above the goal generally accepted of $35 \%$ for satellite ocean colour chlorophyll estimates.

We have performed regression and correlation analyses between the time-series of ANC measured at KGI and the time-series of chl $a$ concentrations in the potential source areas (Bellingshausen-Amundsen Sea, Weddell Sea, southern Argentinean shelf and southern Chilean coast) separately. Therefore, sub-areas of equal size (square boxes in Fig. 1) were defined based on the regional mean chl $a$ composite image corresponding to the atmospheric sampling period at KGI (from September 1997-December 1998). Dimensions and location of the boxes were also based on the total dimension of observed chl $a$ patches. The time series for concentration at the $i$-th $(i=1,2,3,4)$ area was obtained by the monthly average of the results among their boxes, in the following way: for the Bellingshausen-Amundsen Sea: BA1 $\left(69-74^{\circ} \mathrm{S}, 77-82^{\circ} \mathrm{W}\right), \mathrm{BA} 2\left(69-74^{\circ} \mathrm{S}, 72-77^{\circ} \mathrm{W}\right)$, and BA3 $\left(66-71^{\circ} \mathrm{S}, 67-72^{\circ} \mathrm{W}\right)$, for the Weddell Sea: W1 $\left(71-76^{\circ} \mathrm{S}\right.$, $\left.55-60^{\circ} \mathrm{W}\right)$, W2 $\left(71.5-76.5^{\circ} \mathrm{S}, 50-55^{\circ} \mathrm{W}\right)$, and $\mathrm{W} 3\left(72-77^{\circ} \mathrm{S}\right.$, $\left.45-50^{\circ} \mathrm{W}\right)$, for the southern Argentinean shelf: SAS1 $\left(44-49^{\circ} \mathrm{S}, 63-68^{\circ} \mathrm{W}\right)$, SAS2 $\left(44-49^{\circ} \mathrm{S}, 58-63^{\circ} \mathrm{W}\right)$, SAS3 $\left(49-54^{\circ} \mathrm{S}, 64-69^{\circ} \mathrm{W}\right)$, and SAS4 $\left(49-54^{\circ} \mathrm{S}, 59-64^{\circ} \mathrm{W}\right)$ and finally for the southern Chilean coast: $\mathrm{SC} 1\left(44-49^{\circ} \mathrm{S}\right.$, $\left.73-78^{\circ} \mathrm{W}\right)$, and SC2 (49-54 $\left.{ }^{\circ} \mathrm{S}, 73-78^{\circ} \mathrm{W}\right)$.

The synoptic scale atmospheric transport of aerosols from the four postulated source areas to KGI was inferred on the basis of monthly regional surface wind current diagrams compiled from NCEP/NCAR re-analysis (Kalnay et al. 1996, Kistler et al. 2001). Additionally, an AWS $\left(62^{\circ} 05^{\prime} 08^{\prime \prime} \mathrm{S}, 58^{\circ} 23^{\prime} 37^{\prime \prime} \mathrm{W}, 20 \mathrm{~m}\right.$ a.s.l.) installed at the Comandante Ferraz station provided intensity and direction of wind data. The in situ meteorological records were

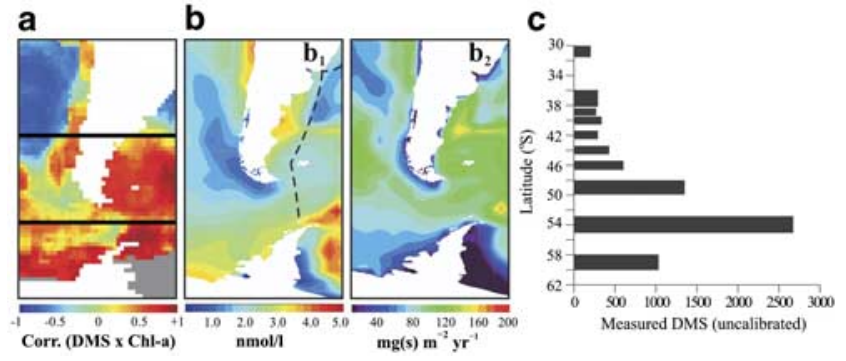

Fig. 2. a. Correlation map between monthly aqueous DMS concentrations from Kettle \& Andreae (2000) and monthly chl $a$ from SeaWiFS, 2002-04 (based on Vallina et al. 2006). $\mathbf{b}_{1}$. Modelled annual mean DMS atmosphere flux (based on Kloster et al. 2005). $\mathbf{b}_{\mathbf{2}}$. Modelled annual mean DMS surface concentrations (based on Kloster et al. 2005). c. In situ DMS measurements (this work). Dashed line is the vessel track.

compared with NCEP/NCAR data in order to evaluate differences between the local wind structure, which is induced by geomorphology and katabatic effects, and the regional wind pattern. Meteorological data used here was downloaded from http://antartica.cptec.inpe.br/ (accessed November 2006).

\section{Results and discussion}

Modelled and in situ databases of atmospheric DMS and $\mathrm{CCN}$ at the Southern Ocean show that the parameters covariate significantly (Vallina et al. 2006). This suggests that DMS may significantly contribute to $\mathrm{CCN}$ burden in that region (Vallina et al. 2007). The latitudinal profile of atmospheric DMS from Rio de Janeiro, through the Patagonian continental shelf, up to King George Island on the northern Antarctic Peninsula, including the oligotrophic environments of the subtropical south-western Atlantic to high productivity regions of the Southern Ocean, resulted in substantial increase of DMS concentrations between latitudes $48^{\circ}$ and $50^{\circ} \mathrm{S}$ (Fig. 2) well in accordance with modelled DMS proposed by Kloster et al. (2005). At a close sub-Antarctic site, DMS was measured by other authors. Turner et al. (1995) performed two simultaneous cruises through the Drake Passage to the Bellingshausen Sea from October-December 1992. Overall, average surface water concentrations for DMS was $2 \mathrm{nM}(0.15-27 \mathrm{nM})$. In situ measurements of DMS and methane sulphonic acid (MSA) at Halley Station, Antarctica $\left(75^{\circ} \mathrm{S}, 26^{\circ} \mathrm{W}\right)$ were conducted during February 2004-February 2005. During that period, DMS was observed in the atmosphere at Halley all year around (average $38.1 \pm 43$ pptv) with a maximum monthly average value of $113.6 \pm$ 52 pptv in February 2004 coinciding with a minimum in sea ice extent. MSA was generally low throughout the year, with an annual average of $42 \mathrm{ng} \mathrm{m}^{-3}$, however MSA $/ \mathrm{nss}^{-S} \mathrm{~S}_{4}^{-2}$ ratios were high implying a dominance of the addition oxidation route via DMS (Read et al. 2008). 

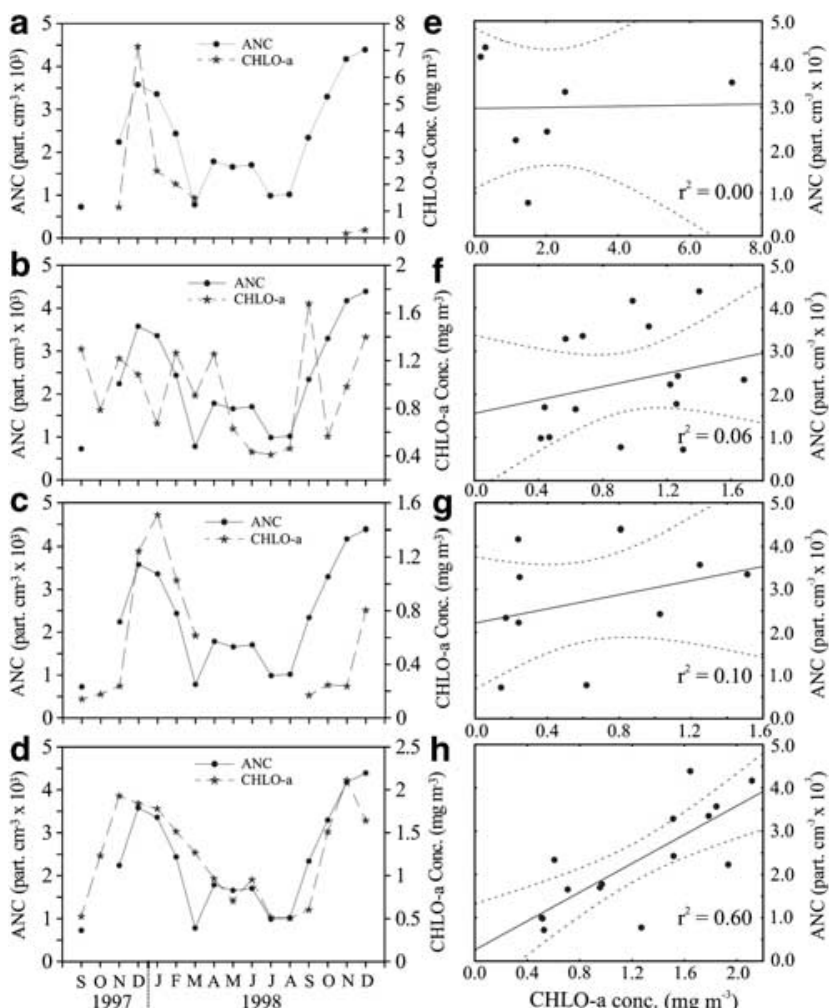

Fig. 3. The left column shows superimposed monthly ANC at KGI and chl $a$ for a. the Weddell Sea, b. the southern Chilean coast, c. the Bellingshausen-Amundsen Sea, and d. the southern Argentine shelf. The right column shows regression between ANC and chl $a$ from e. the Weddell Sea, f. the southern Chile coast, g. the Bellingshausen-Amundsen Sea and $\mathbf{h}$. the southern Argentine shelf, with corresponding $95 \%$ confidence bands.

Concerning the ANC measured at KGI, the mean value ( \pm 1 standard deviation) from September 1997-December 1998 was $2.3 \pm 1.2 \times 10^{3} \mathrm{~N} \mathrm{~cm}^{-3}$ (minimum of $0.7 \times 10^{3} \mathrm{~N} \mathrm{~cm}^{-3}$ in September 1997 and maximum of $4.4 \times 10^{3} \mathrm{~N} \mathrm{~cm}^{-3}$ in December 1998). One important feature of ANC over KGI is its well-defined seasonal variability (Fig. 3). Lower ANC values occur during the winter (March-September) while peaks coincide with the summer (approximately OctoberFebruary). This result is consistent with DMS and MSA increases during spring-summer seasons observed during the cruise of the RRS Bransfield between 2 October 1992 and 10 January 1993 that covered a geographical area which included the Falkland Islands (Islas Malvinas), the Antarctic Peninsula and the Weddell Sea (Davison et al. 1996).

Chl $a$ concentrations were not available for all Antarctic circumpolar regions, especially in the BellingshausenAmundsen and Weddell seas due to sea ice expansion during the winter season and partially during spring and autumn. The average chl $a$ concentration in the Weddell Sea sector was $2.1 \pm 2.4 \mathrm{mg} \mathrm{m}^{-3}$, peaking in December 1997. As shown in Fig. 3a, no chl $a$ values were available in the Weddell Sea

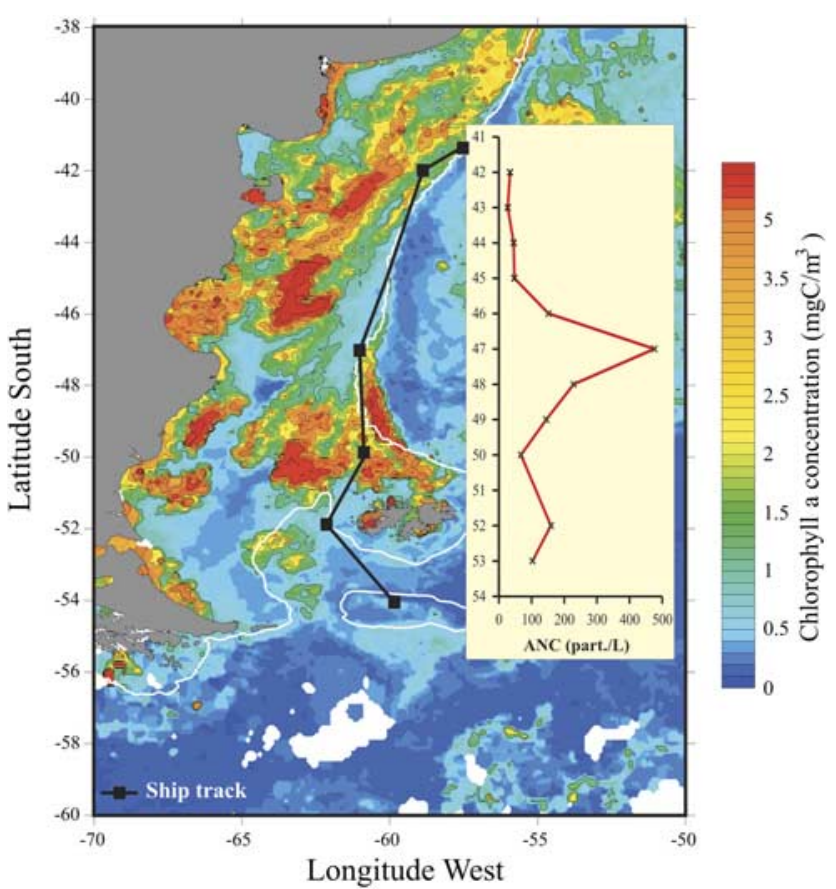

Fig. 4. Chl $a$ image from an 8 days (23-30 Oct 2008) composite using SeaWiFS from the Giovanni server at NASA. The solid black line is the approximate vessel route from Rio de Janeiro to King George Island and the white line is the $200 \mathrm{~m}$ isobath.

between April and October 1998. Chl $a$ concentrations in the Bellingshausen-Amundsen Sea sector were much lower compared to the Weddell Sea values, with a mean value of $0.6 \pm 0.5 \mathrm{mg} \mathrm{m}^{-3}$, peaking in January. Considering the selected sub-areas in the Bellingshausen-Amundsen Sea sector, no chl $a$ concentration data was available for the period April-August 1998, in contrast to the sites located further north (the southern Chilean coast and the southern Argentinean shelf) where chl $a$ databases are available continuously. For the southern Chilean coast sector, mean concentration was $0.4 \mathrm{mg} \mathrm{m}^{-3}$ (Fig. 3b) peaking in September with a secondary peak in December, while in the southern Argentinean shelf sector a mean of $1.2 \pm 0.6 \mathrm{mg} \mathrm{m}^{-3}$ (Fig. 3d) was found and a peak in November. Chl $a$ concentration was highest in the Weddell Sea sector with values four times higher than the other selected regions, followed by the southern Argentinean shelf sector. The Spearman rank correlation coefficients $\left(r_{\mathrm{S}}\right)$ obtained between ANC on KGI and chl $a$ concentrations from the Weddell Sea, the southern Chilean coast, the Bellingshausen-Amundsen Sea and the southern Argentinean shelf were $r_{\mathrm{S}}=-0.29(n=7), r_{\mathrm{S}}=$ $+0.31(n=15), r_{\mathrm{S}}=+0.48(n=10), r_{\mathrm{S}}=+0.76(n=15)$, respectively (Fig. 3e-h) and only in the southern Argentinean shelf sector was statistically significant $(P<0.05)$.

From the correlation coefficients depicted in Fig. $3 \mathrm{e}-\mathrm{h}$, the higher value was attributed to chl $a$ occurrence at the 

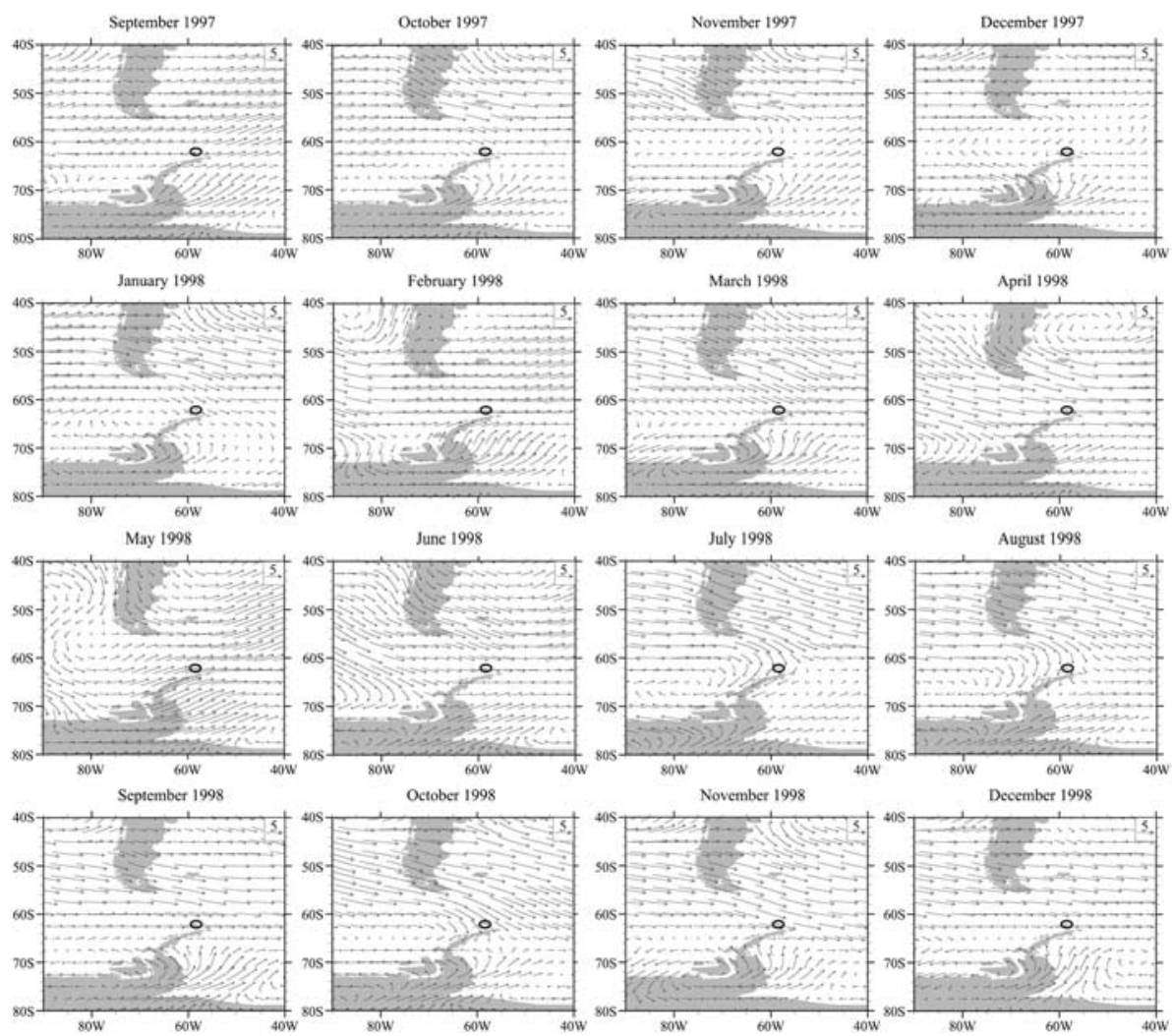

Fig. 5. Regional monthly mean wind vectors at sea level compiled from NCEP/NCAR re-analysis between September 1997 and December 1998. Location of King George Island is indicated by a circle. southern Argentinean shelf region and the atmospheric ANC suspended at KGI. Chl $a$ inferred from the three other regions were not significantly correlated with ANC measured at KGI. The absence of chl $a$ production around the Antarctic Peninsula during several months of the winter due to both sea ice cover and darkness suggest that the ANC background at KGI during the winter can be attributed to the biological production occurring in the northern sectors. Each of the four selected regions presented particular frequency data distribution characteristics. In the Weddell Sea and the southern Chilean coast (Fig. 3a \& b) maximum chl $a$ concentrations were characterized by rapid transient peaks at the beginning of the summer (November-December 1997). Particularly in the southern Chilean coast it was skewed to the month of September in 1997. On the other hand, both the Bellingshausen-Amundsen Sea and the southern Argentinean shelf sectors (Fig. 3c \& d) presented a peak of concentration smoothed during the summer. The season of maximum concentrations in these regions lasts for about 3-4 months (beginning in November), similar to ANC time variation. Focusing on the seasonal variability of ANC, we found that chl $a$ pattern in the southern Argentinean shelf sector can explain the general behaviour of that parameter measured on KGI between 1997 and 1998 (Fig. 3).

During the 2008 oceanographic cruise (from 23-27 October) we performed in situ ANC measurements specifically at the Patagonian continental shelf (within the latitudinal band of $c$. $38-60^{\circ} \mathrm{S}$ ) in order to establish a direct comparison with regional chl $a$ images for the corresponding period. In this case, the onboard cloud condensation counter was the same instrument employed for the KGI monitoring. Figure 4 depicts a chl $a$ image from an eight days composite using SeaWiFS data between 23 and 30 October 2008 (the eight days window allowed elimination of most of the clouds). Data was downloaded at $0.1^{\circ} \times 0.1^{\circ}$ resolution from the Giovanni server at NASA. The white line is the $200 \mathrm{~m}$ isobath, to visualize the shelf break. As one can see the values are quite high, with regions above $5 \mathrm{mg} \mathrm{m}^{-3}$. On board measurements indicated a significant increase of ANC in the vicinity of the central part of bloom occurrence, probably as a result of surrounding biological activity, which indicates that the Patagonian continental shelf chl $a$ blooms are associated with significant ANC increases. From Fig. 4 a discrepancy of a few degrees of latitudes can be observed between the peak location and the bloom centre. This could be attributed to several processes such as the DMS oxidation time in the atmosphere prior to forming sulphate aerosols. Also, nucleation of new aerosols from sulphuric acid occurs mainly in the free troposphere and the production of $\mathrm{CCN}$ via this mechanism may take several days, involving the vertical transport of DMS, its oxidation, particle nucleation, growth and re-entrainment of particles into the boundary layer. Therefore, ANC increase due to this mechanism may happen downwind from the source (Woodhouse et al. 2008).

In order to explore the contribution of each potential source area to the apportionment of ANC measured on KGI, we have 


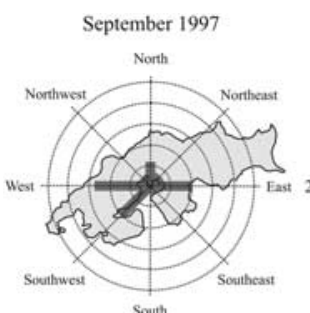

South
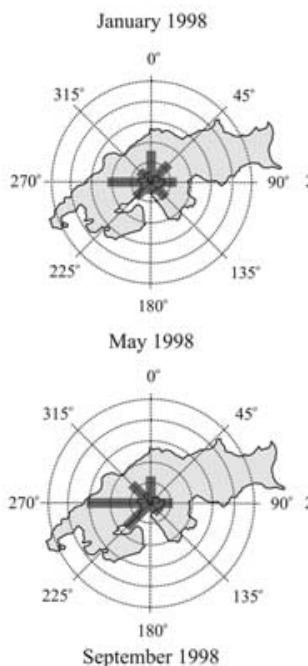

September 1998

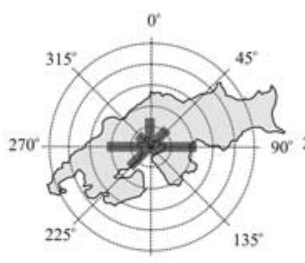

180

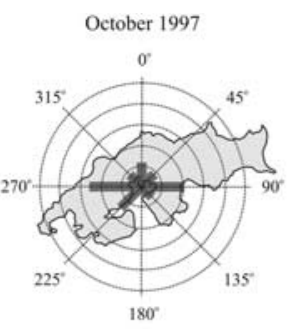

February 1998

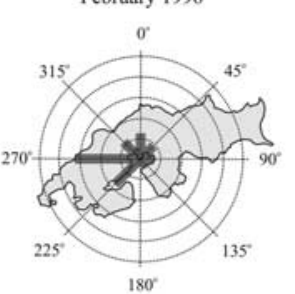

June 1998

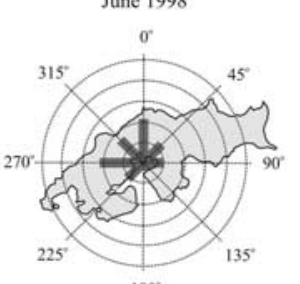

$180^{\circ}$ October 1998

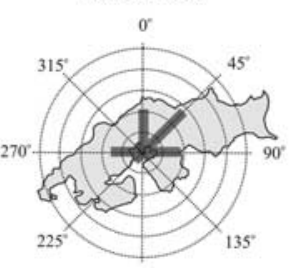

$180^{\circ}$

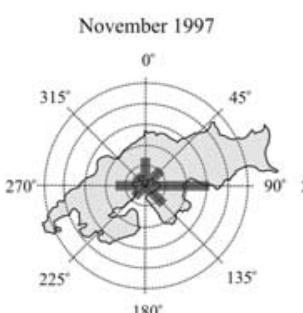

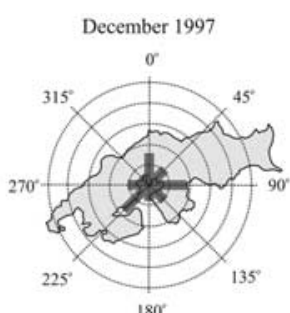

180
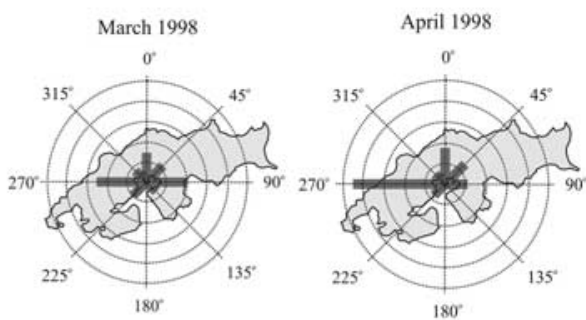

July 1998

180
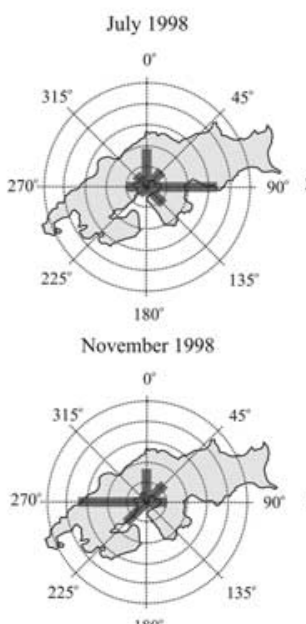

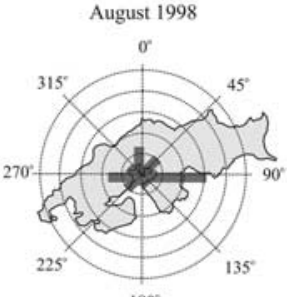

180

December 1998

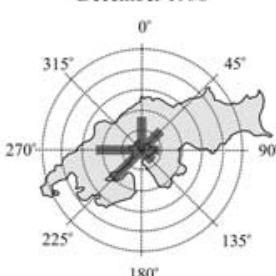

Fig. 6. Wind frequency and direction from the AWS at King George Island during the period September 1997-December 1998. Concentric circles represent intervals of $10 \%$. investigated the regional and local synoptic wind conditions during the sampling period. Figure 5 depicts the surface wind currents for each month provided by NCEP/NCAR re-analysis and Fig. 6 shows the in situ wind frequency distribution centred at the AWS installed on KGI. Figure 5 shows the regional influence of the sea level westerly winds (particularly between July and November) between southern South America and the tip of the Antarctic Peninsula, where KGI is located. This points to the potential influence of the southern Argentinean shelf and the southern Chilean coast regions with respect to the biogenic particles apportionment on KGI.

Although the in situ meteorological data may be constrained by orographic aspects and katabatic winds, it can be used, roughly, to select geographical sectors associated with chl $a$ (and presumably DMS production) potential source areas. It can be observed in Fig. 6 that on KGI the main synoptical influence derives from the zonal wind that blows through the Drake Passage, around latitude $60^{\circ} \mathrm{S}$, from the Pacific to the Atlantic Ocean. The eastward direction also occurs with relatively high frequency and it is attributed to the clockwise cyclonic movement while they migrate through the region (Pereira 1990, Evangelista \& Pereira 2002, Pereira et al. 2006).

During the monitoring period, south-east, south and northeast sectors contributed very little to the total frequency of winds observed on KGI, as indicated by Fig. 6. From this figure it can be observed that the two major frequency wind components are associated with the west and east directions. AWS data (Fig. 6) probably underestimate the southern Chilean coast contribution due to reasons presented above, while NCEP/NCAR re-analysis (Fig. 5) pointed out the higher influence of the southern Chilean coast associated with the westerly winds. The northern wind influence (the southern Chilean coast and the southern Argentinean shelf) comprised around $75 \%$ of the wind frequency reaching KGI. Also the lower influence of the Weddell Sea sector (c. 15\%) was identified by both analyzed methods.

Despite the proximity of KGI to sub-Antarctic areas characterized by high ocean chl $a$ concentration such as the Weddell and the Bellingshausen-Amundsen sea sectors, there is a considerably higher association between ANC measured on KGI in the low atmosphere and the ocean 
chl $a$ concentration at the southern Argentinean shelf (the southern Chilean coast presented lesser correlation). Based on the data used in this study, a combination of high chl $a$ concentration areas located at the northern latitudes of KGI associated with favourable wind circulation makes the southern Argentinean shelf and the southern Chilean coast regions potential contributors to the apportionment of marine derived aerosols (probably dominated by sulphates) over the South Shetland Islands.

\section{Conclusions}

Herein we have explored the understanding of ANC interannual variability on KGI and its association with marine productivity that may result in DMS oxidation products, marine primary organic matter (e.g. microcolloid aggregates) and secondary organic aerosols, all potential components of ANC. In this sense we suggest that chl $a$ variability is the major process controlling the summer ANC seasonal peak, despite the inorganic compounds of terrigenous and marine sources. Our interpretations were based on the averaged monthly ANC data, which covered a period long enough to include secondary processes from chl a blooming to aerosol formation. A contribution of dust micro-particles eroded from the Argentine Patagonian semi-desert to the ANC, although not discarded, is probably of lesser importance to the annual variability, since the flux of dust into the southern latitudes is episodic (Evangelista et al. 2010).

In this work, we employed a dataset of meteorological and environmental parameters in order to identify the main source regions of aerosol arriving at the northern tip of the Antarctic Peninsula (KGI), from September 1997December 1998. From averaged SeaWiFS chl $a$ images we selected four main potential source areas: the BellingshausenAmundsen Sea, the Weddell Sea, the southern Argentinean shelf and the southern Chilean coast. Correlations and associations among NCEP/NCAR regional wind pattern, local AWS wind data, monthly chl $a$ concentration and aerosol number concentration allowed us to conclude that the southern Argentinean shelf region is more likely the main contributor of ANC (presumably through S particles) at KGI, despite the proximity of this island to Antarctic productive regions. We attribute the high correlation found to a combination of two factors: 1) the favourable regional surface wind circulation, and 2) the high occurrence of diatoms and the Coccolithophorid species like Emiliania huxleyii, which are known to be associated with high DMS emissions in the Southern Ocean.

\section{Acknowledgements}

Part of the images and data used in this study were acquired using the GES-DISC Interactive Online Visualization and Analysis Infrastructure (Giovanni) as part of the NASA's
Goddard Earth Sciences (GES) Data and Information Services Center (DISC). NCEP/NCAR re-analysis data was provided by the NOAA/OAR/ESRL PSD, Boulder, CO, USA, from their Web site at http://www.cdc.noaa.gov/. The authors would like to thank the Brazilian Antarctic Program (PROANTAR) and the Brazilian National Council for Scientific and Technological Development (CNPq) for logistical and financial support (Project 55.0353/02-0). We also thank CAPES (Coordenação de Aperfeiçoamento de Pessoal de Nível Superior) for funding scholarship. The constructive comments of the reviewers are also gratefully acknowledged.

\section{References}

Andreae, M.O. \& Crutzen, P.J. 1997. Atmospheric aerosols: biochemical sources and role in the atmospheric chemistry. Science, 276, 1052-1058.

Arrigo, K.R., DiTullio, G.R., Dunbar, R.B., Robinson, D.H., van Woert, M., Worthen, D.L. \& Lizotte, M.P. 2000. Phytoplankton taxonomic variability in nutrient utilization and primary production in the Ross Sea. Journal of Geophysical Research - Oceans, 105, 8827-8846.

Braun, M., Saurer, H. \& Goßmann, H. 2004. Climate, energy fluxes and ablation rates on the icecap of King George Island. Brazilian Antarctic Research, 4, 87-103.

Charlson, R.J., Lovelock, J.E., Andreae, M.O. \& Warren, S.G. 1987. Oceanic phytoplankton, atmospheric sulphur, cloud albedo and climate. Nature, 326, 655-661.

Correia, A.L., Artaxo, P. \& Maenhaut, W. 1998. Monitoring of atmospheric aerosol particles on the Antarctic Peninsula. Annals of Glaciology, 27, 560-564.

Crocker, K.M., Ondrusek, M.E., Petty, R.L. \& Smith, R.C. 1995. Dimethyl sulphide, algal pigments and light in an Antarctic Phaeocystis sp. bloom. Marine Biology, 124, 335-340.

Dalia, K.C., Evangelista, H., Simões, J.C. \& Pereira, E.B. 2004. Sazonalidade de aerossóis atmosféricos e microanálise individual por EDS em testemunho de gelo da ilha Rei George. Brazilian Antarctic Research, 4, 25-36.

Davison, B., O’Dowd, C., Hewitt, C.N., Smith, M.H., Harrison, R.M., Peel, D.A., Wolff, E.W., Mulvaney, R., Schwikowski, M. \& Baltensperger, U. 1996. Dimethyl sulphide and its oxidation products in the atmosphere of the Atlantic and Southern oceans. Atmospheric Environment, 30, 1895-1906.

Ditullio, G.R., Grebmeier, J.M., Arrigo, K.R., Lizotte, M.P., Robinson, D.H., Leventer, A., Barry, J.B., van Woert, M.L. \& Dunbar, R.B. 2000. Rapid and early export of Phaeocystis antarctica blooms in the Ross Sea, Antarctica. Nature, 404, 595-598.

Evangelista, H. \& Pereira, E.B. 2002. Radon flux at King George Island, Antarctic Peninsula. Journal of Environmental Radioactivity, 61, 283-304.

Evangelista, E., Maldonado, J., Dos Santos, E.A., Godoi, R.H.M., Garcia, C.A.E., Garcia, V.M.T., Jonhson, E., Dias da Cunha, K., Leite, C.B., van Grieken, R., van Meel, K., Makarovska, Y. \& Gaiero, D.M. 2010. Inferring episodic atmospheric iron fluxes in the western South Atlantic. Atmospheric Environment, 44, 703-712.

Ferron, F.A., Simões, J.C., Aquino, F.E. \& Setzer, A.W. 2004. Air temperature time series for King George Island, Antarctica. Brazilian Antarctic Research, 4, 155-169.

FitzGERALD, J.W. 1991. Marine aerosols: a review. Atmospheric Environment, 25, 533-545.

Garcia, C.A.E., Garcia, V.M.T. \& McClain, C.R. 2005. Evaluation of SeaWiFS chlorophyll algorithms in the south-western Atlantic and Southern Oceans. Remote Sensing of Environment, 95, 125-137.

Garibotti, I.A., Vernet, M., Ferrario, M.E., Smith, R.C., Ross, R.M. \& Quetin, L.B. 2003. Phytoplankton spatial distribution patterns along the western Antarctic Peninsula (Southern Ocean). Marine Ecology Progress Series, 261, 21-39. 
Gayoso, M.A. 2001. Observations on Alexandrium tamarense (Lebour) Balech and other dinoflagellate populations in Golfo Nuevo, Patagonia (Argentina). Journal of Plankton Research, 23, 463-468.

Gloersen, P., Campbell, W.J., Cavalieri, D.J., Comiso, J.C., Parkinson, C.L. \& Zwally, H.J. 1992. Arctic and Antarctic sea ice, 1978-1987: satellite passive-microwave observations and analysis. Washington, DC: National Aeronautics and Space Administration, $290 \mathrm{pp}$.

Holm-Hansen, O., Naganobu, M., Kawaguchi, S., Kameda, T., Krasovski, I., Tchernyshkov, P., Priddle, J., Korb, R., Brandon, M., Demer, D., Hewitt, R.P., Kahru, M. \& Hewes, C.D. 2004. Factors influencing the distribution, biomass, and productivity of phytoplankton in the Scotia Sea and adjoining waters. Deep-Sea Research I, 51, 1333-1350.

Kalnay, E., Kanamitsu, M., Kistler, R., Collins, W., Deaven, D., Gandin, L., Iredell, M., Saha, S., White, G., Woollen, J., Zhu, Y., LeetmaA, A., Reynolds, B., Chelliah, M., Ebisuzaki, W., Higgins, W., Janowiak, J., Mo, K.C., Ropelewski, C., Wang, J., Jenne, R. \& Joseph, D. 1996. The NCEP/NCAR 40-year reanalysis project. Bulletin of the American Meteorological Society, 77, 437-471.

Kettle, A.J. \& Andreae, M.O. 2000. Flux of dimethyl sulphide from the oceans: a comparison of updated dataset and flux models. Journal of Geophysical Research, 105, 26793-26808.

Kirkevag, A., Iversen, T. \& Dahlback, A. 1999. On radiative effects of black carbon and sulfate aerosols. Atmospheric Environment, 33, 2621-2635.

Kistler, R.E., Kalnay, W., Collins, S., Saha, G., White, J., Woollen, M., Chelliah, W., Ebisuzaki, M., Kanamitsu, V., Kousky, H., van den Dool, J.R. \& FIORINo, M. 2001. The NCEP-NCAR 50-year reanalysis: monthly means CD-ROM and documentation. Bulletin of the American Meteorological Society, 82, 247-268.

Kloster, S., Feichter, J., Maier-Reimer, E., Six, D., Stier, P. \& Wetzel, P. 2005. DMS cycle in the marine ocean-atmosphere system - a global model study. Biogeosciences Discussions, 2, 1067-1126.

Langmann, B., Herzog, M. \& Graf, H.-F. 1998. Radiative forcing of climate by sulphate aerosols as determined by a regional circulation chemistry transport model. Atmospheric Environment, 32, 2757-2768.

LizotTe, M.P. 2001. The contribution of sea ice algae to Antarctic marine primary production. American Zoology, 41, 57-73.

Maring, H. \& Schwartze, G. 1994. A condensation particle counter for long-term continuous use in the remote marine environment. Atmospheric Environment, 28, 3293-3298.

McConnell, J.R., Aristarain, A.J., Banta, J.R., Edwards, P.R. \& SimÕes, J.C. 2007. 20th-century doubling in dust archived in an Antarctic Peninsula ice core parallels climate change and desertification in South America. Proceedings of the National Academy of Science of the United States of America, 104, 5743-5748.

Moore, J.K. \& Аввотт, M.R. 2000. Phytoplankton chlorophyll distributions and primary production in the Southern Ocean. Journal of Geophysical Research, 105, 28 709-28 722.

PABI, S. \& ARRIGO, K.R. 2006. Satellite estimation of marine particulate organic carbon in waters dominated by different phytoplankton taxa. Journal of Geophysical Research, 111, 10.1029/2005JC003137.
Pereira, E.B. 1990. Radon-222 time series measurements in the Antarctic Peninsula (1986-1987). Tellus, 42B, 39-45.

Pereira, E.B., Evangelista, H., Pereira, K.C.D. \& Setzer, A.W. 2006. Apportionment of black carbon in the South Shetland Islands, Antarctic Peninsula. Journal of Geophysical Research - Atmospheres, 111, art. no. DO3303.

Read, K.A., Lewis, A.C., Bauguitte, S., Rankin, A.M., Salmon, R.A., Wolff, E.W., Saiz-Lopez, A., Bloss, W.J., Heard, D.E., Lee, J.D. \& Plane, J.M.C. 2008. DMS and MSA measurements in the Antarctic boundary layer: impact of $\mathrm{BrO}$ on MSA production. Atmospheric Chemistry and Physics Discussion, 8, 2657-2694.

Rivas, A.L. 2006. Quantitative estimation of the influence of surface thermal fronts over chlorophyll concentration at the Patagonian shelf. Journal of Marine Systems, 63, 183-190.

Rivas, A.L., Dogliotti, A.I. \& Gagliardini, D.A. 2006. Seasonal variability in satellite-measured surface chlorophyll in the Patagonian shelf. Continental Shelf Research, 26, 703-720.

Romero, S.I., Piola, A.R., Charo, M. \& Garcia, C.A.E. 2006. Chlorophyllalpha variability of Patagonia based on SeaWiFS data. Journal of Geophysical Research - Oceans, 111, 10.1029/2005JC003244.

Saraceno, M., Provost, C. \& Piola, A.R. 2005. On the relationship between satellite-retrieved surface temperature fronts and chlorophyll-a in the western South Atlantic. Journal of Geophysical Research Oceans, 110, 11010.11029/12004JC002736.

Setzer, A.W. \& Harter, F. 2004. Estudo das temperaturas mínimas de julho 1995 na Estação Antártica Comandante Ferraz, Ilha Rei George. Brazilian Antarctic Research, 4, 171-181.

Signorini, S.R., Garcia, V.M.T., Piola, A.R., Garcia, C.A.E., Mata, M.M. \& McClain, C.R. 2006. Seasonal and interannual variability of calcite in the vicinity of the Patagonian shelf break. Geophysical Research Letters, 33, 10.1029/2006GL026592.

Toro, J.E., Paredes, P.I. \& Villagra, D.J. 1999. Phytoplankton distribution and oyster, Ostrea chilensis (Philippi, 1845), growth at Putemun Channel, southern Chile. New Zealand Journal of Marine and Freshwater Research, 33, 499-513.

Turner, J. 2004. The El Niño-Southern Oscillation and Antarctica. International Journal of Climatology, 24, 1-31.

Turner, S.M., Nightingale, P.D., Broadgate, W. \& Liss, P.S. 1995. The distribution of dimethyl sulphide and dimethylsulphoniopropionate in Antarctic waters and sea ice. Deep-Sea Research II, 42, 1059-1080.

ValLina, S.M., Simó, R. \& Gassó, S. 2006. What controls CCN seasonality in the Southern Ocean? A statistical analysis based on satellite-derived chlorophyll and $\mathrm{CCN}$ and model-estimated $\mathrm{OH}$ radical and rainfall. Global Biogeochemical Cycles, 20, 10.1029/2005GB002597.

Vallina, S.M., Simó, R., Gassó, S., De Boyer-Montégut, C., Del Río, E., JuRADO, E. \& DACHS, J. 2007. Analysis of a potential 'solar radiation dose-dimethyl sulphide-cloud condensation nuclei' link from globally mapped seasonal correlations. Global Biogeochemical Cycles, 21, $10.1029 / 2006 \mathrm{~GB} 002787$.

Woodhouse, M.T., Mann, G.W. \& Carslaw, K.S. 2008. New directions: the impact of oceanic iron fertilisation on cloud condensation nuclei. Atmospheric Environment, 42, 5728-5730. 